\title{
Constructing vocational education capital: An analysis of symbolic values in the Swedish VET system of 1918
}

\author{
Åsa Broberg \\ Stockholm University, Sweden (asa.broberg@edu.su.se)
}

\begin{abstract}
This article explores ways of creating educational capital in vocational education and training in Sweden during a period in the early 20th century when vocational learning was first institutionalised as education. As such, at the same time it had to create itself and submit to the established educational system. This process is the focus of the article; it is examined by using concepts from Bourdieu's capital-theory. In this perspective, vocational education and training as an educational form is considered part of the field of education. However, the main focus of the analysis is the newly formed education for vocational learning as a field of vocational education where a particular vocational educational capital was created. The aim is to illuminate ways of creating vocational education capital by borrowings, crossovers and reinventions of values from two traditions of learning and knowledge production: apprenticeship in the guilds and education in academia. The symbols from both crafts and academia were passed on into the early VET system through its institutions and actors. It materialised in titles, artefacts and rituals that that are presented in archives, journals and school memorial books.
\end{abstract}

Keywords: history of vocational education, symbolic capital, educational capital, field of vocational education, sociology of education 
Åsa Broberg

\section{Introduction}

This article explores a phenomenon appearing in the early $20^{\text {th }}$ century when vocational education in the Nordic countries was organised as an educational form rather than as vocational learning mainly associated with apprenticeship and the logics of working life. It is a process of constructing vocational educational capital as symbolic asset in relation to education as well as to trade and industry. The systems of national vocational education and training (VET) developed differently in terms of juridical, economical, and ideological aspects, and in division of responsibility between government and trade and industry. The contrasts of both differences and similarities contribute to understand the characters of VET systems, but as pointed out in a recent study more can be done to broaden this understanding by investigating previously unexplored relations such as the proximity to compulsory education (Hellstrand, 2020; Michelsen, 2018). This article takes that relation into account and is a historical study of early Swedish VET as a social field where education capital was constructed combining learning traditions and recontextualising values. It also provides examples of this process. The case is $20^{\text {th }}$ century Swedish VET, but the Nordic countries experienced the same development of national vocational as well as general compulsory education during the period (Michelsen, 2018). The creating of a specific vocational education capital, which this article explores, can thus be assumed to have taken place in a similar way in the Nordic countries, but with outcomes specific to each nation depending on its relations to general and academic education.

In 1918 Sweden got its first government-regulated and government-financed vocational education and training (VET) system. At the same time, compulsory education for the majority of young people was reformed and extended to offer two years' continuation following the five-year compulsory general education, 'folkskolan'. The curricula of this education were to contain mainly practical subjects and the aim was to prepare for working life or for further education in the newly established vocational education (Lindell, 1992). The combination of fiveyear compulsory education (age 7-11), two-year practical continuation education (age 12-13), and vocational education (age 14-15/17), formed a working-class educational track within a segmented national education system. Another, academic track, for the upper classes, was through the 'läroverk' (age 9-15) that prepared for university education and higher offices. A new institution for education regardless of its content has to conform to the preceding conception and form of organised schooling. Thus, already established educational systems have power over the purpose and aims, organisation and content of new educations. In this case, the 'läroverk' with its long historical traditions and the somewhat later 'folkskola' were the educational institutions that positioned vocational education (Lindensjö \& Lundgren, 2014). In the history of education, in this case the history of Swedish VET, two processes can be identified a process of contemporary 
reproduction and, at the same time, a process of historical reproduction. The first process reproduces knowledge and skills considered necessary for production and to live in a society. In themselves this knowledge and these skills have historical genetics. The second process, the historical reproduction of education, reproduces the organisation of knowledge (priorities and aims) and learning (Lindensjö \& Lundgren, 2014).

When vocational learning began to form as an education in an educational system from the early $20^{\text {th }}$ century, VET had to manage two important tasks: to constitute itself within a pre-existing system of education and to gain recognition as an educational option with social as well as vocational credibility. Hence, the contemporary reproduction of vocational knowledge and skills with its legacy of crafts became part of the historical reproduction of education in Sweden. Although conditioned by the history of education, conforming vocational learning to vocational education was, and still is, not a predetermined process. The aim of this article is to illuminate ways of creating vocational education capital by borrowings, crossovers and reinventions of values from two traditions of learning and knowledge production: apprenticeship in the guilds and academia.

The time frame of the early Swedish VET system is 1918-1971, but this article centres on the period 1940-1970 as it is possible to identify periods of rise and fall in the VET model emerging from the 1918 reform. The period 1940-1970 can, in this case, be defined as a peak performance for the model in terms of increasing number of students and increased attention in education policy debates. ${ }^{1}$ The investigation takes as its point of departure the theoretical construction of VET as a social field; and the research questions guiding the investigation into the construction work of education capital are: 1) What traditions and already existing expressions of symbolic values were available for the construction of a vocational education capital? 2) What kinds of actions can be interpreted as contributing to building up symbolic capital specific to vocational education and training as an educational institution?

Following a presentation of the theoretical considerations and method, the investigation falls into two parts. Part one describes the early Swedish national VET as a social field and its different traditions as a carrier of symbolic values. Part two analyses these values as expressed in symbolic actions and artefacts.

\section{Theoretical considerations and method}

Bourdieu's theory of capital aimed to explain social production and reproduction of hierarchical structures in society. Educational systems in particular have been fruitfully investigated using the key concepts of this theory. Interestingly enough, vocational education has not been subject to many such attempts. ${ }^{2}$ One explanation may be that VET is rarely considered in its own right but rather as an integrated part of a national education system (Berner, 1989). However, for 
the aim of this article it is just as important to acknowledge relational aspects between general, academic education and VET as to separate the two as different historical and cultural traditions of knowledge production and social reproduction. The assumption made is that VET as an institutionalised education is formed by tensions embedded in differences and similarities of traditions and the educational capital; the currency of vocational education in society can be perceived through symbols created in that tension.

The analytical tools used in this investigation are the concepts of social field, symbolic capital and habitus. These concepts are most comprehensible when the empirical material and the concepts are tied to an analysis of the data (Bourdieu, 1995). The Bourdieuan concepts in this investigation operates on two levels for the purpose of a) setting the scene for creating vocational education capital, and b) exploring ways of creating vocational education capital.

The empirical material comprises text and photographs from a journal, school archives and memory books. The relevance of the material pertains to the producers as well as the products. The material is produced by people engaged in VET on different levels and positions. The products, in this case means perceptions of VET and VET values revealing themselves in descriptions and action. The different types of sources will be briefly introduced here and further described in connection to its use in relation to the analysis.

Tidskrift för praktiska ungdomsskolor (TPU) [Journal of Youth Vocational Schools] was a journal published by the organisation Svenska yrkesskoleföreningen (SYF) [Association of Swedish Vocational Schools]. This organisation was formed in response to the 1918 VET reform, and its aim was work for the development of Swedish VET. Articles in the journal provide reports of the inner life of VET though portraits, debates, important issues and statements.

Archive material from two vocational schools in Stockholm provides close encounters with actions and practices such as ceremonies and board decisions that provide information about the perception of VET among those who were closely involved in school activities. Minutes, photos and a school song are included in the archive material. All quotes from the source material are translated from Swedish for this article.

Unlike the journal and the archive material, the memory books are not contemporary (and thus not a producer in the field of VET at the time) but included because of the accounts given by former teachers and students describing symbolic events and giving information on aspects of socialisation through vocational education. The books are also used for its photographic material and the descriptions of events that took place at the time.

Since the material include both historical texts (of different genres) and pictures, the method is a combination of content analysis and visual imagery analysis. Historical document analysis is usually carried out within a hermeneutical, interpretative tradition which imply contextualisation and an abductive process 
in the interpretation moving back and forth between the known, the data, the theoretical concepts and the new understanding (Selander \& Ödman, 2004). The context in terms of the Swedish VET in the particular time period is well known through previous research. Sorting out the actions and expressions of a historical process is constructing new knowledge, and this is done by content analysis. The content in the articles, minutes and books was categorised as actions and expressions in accordance with the key theoretical concepts: habitus and capitals of different kind (Watt Boolsen, 2007). Visual material is useful to inform historical and sociological research as it 'depict the physical arrangements [...] of bodies within socially constructed spaces' (Margolis \& Fram, 2007, p. 193). This is important for understanding schooling in the Bourdieuan sense as something embodied and expressed through actions (what and how people do and say things) and symbols. In using both texts and images with a hermeneutical approach it is also important to recognise settings of particular actions and expressions. That means for example, to recognise the authority of School Boards or the informality/formality of an interaction between students or students and teachers.

\section{VET as a social field - setting the scene}

In short, a social field is a system of relations and positions occupied by people and institutions that battle over something that is common to them. A field appears as a structured room, and the structure is established by a history of old battles and acquired positions. Where there is a social field there is a struggle, but the properties or specifics of the struggle are characterised by the particular field (Bourdieu, 1991, 1995). In the case of Swedish VET, the field created around 'the good vocational education' fused together crafts and industry, the parties of the labour market, academics and workers, and I would like to emphasise the roles of the teachers and the students as important groups of interests in the development of early $20^{\text {th }}$ century Swedish VET.

The constitution and development of the 1918 VET system during the early to mid-1900s also provided conditions for a VET field to emerge. Indeed 'a world of its own' (Bourdieu \& Chartier, 2015, p. 16; Broady, 1998b) as a social field has also been described, the VET system was explicitly narrated as 'yrkesskolvärlden' [the world of vocational schools/education] and, equally explicitly, inhabited by 'yrkesskolfolk' [vocational school/education people] (Broberg, 2014; TPU 1:1957, p. 12; TPU 2:1956, p. 25). The need for developing skills for trade and industry was paramount both to traditional vocational groups (crafts) finding themselves under new conditions after the free trade laws of the late $19^{\text {th }}$ century had been implemented, and to representatives of the new industrial groups. The struggle in the early vocational education field concerned defining or deciding what to count as the 'real', or as it was put in its own time, as 'the actual vocational education' (Broberg, 2014). This core education, as we may call it, drew 
heavily on the tradition of the guilds and apprenticeship learning and this legacy gave it its most valuable cultural capital. The relationally contesting part related to the upcoming industrial vocations and how to acquire the knowledge and skills required. Strategies of closure and strategies to break closure developed from the two traditions. Attempts were made to bring in new actors, institutions or symbols to enforce different parts of the field. These actions reveal the intertwined process of contemporary and historical reproduction as vocational learning merged into education. At the same time as new VET educational forms such as in-school workshops competed with apprenticeship, new educations for new industrial professions employed the traditional meriting system of the guilds.

The structure of a field is a state-of-strength ratio between the actors and institutions that battle over the distribution and definitions of the symbolic capital specific to the field. Those who monopolise the specific capital in a specific stateof-strength ratio, according to Bourdieu, have a tendency to use it for conservative strategies, but part of the fields dynamic is that the constitution of the field is dependent on groups challenging the orthodoxy in a previous state (Bourdieu, 1991, 2000).

As a field, VET constituted itself around a common interest in the transfer and development of vocational skills and the qualification system to measure them. For a long time, this had been the responsibility of the guilds, and learning through apprenticeship was the only known way of acquiring practical vocational skills. For the constitution of VET as a field, the silence or obviousness of how to acquire vocational skills had to be broken by actors challenging the doxa (the unquestioned truth) of practical learning within the guild tradition. Before the $20^{\text {th }}$ century, the new actors voicing the question of acquiring vocational skills by education were no threat to the traditional truth of how to acquire them. The formation of VET as a field was dependent on the interest in practical learning from industry challenging conceptions, organisation and evaluation of vocational skill transfer or learning. The head of a corporation did not train the worker himself as the master in a craft workshop; he had to rely on others to educate his workers. His interest in this aspect of business made him challenge the traditional opinion or present alternative ideas about practical learning that forced the door to the doxa of vocational skill transfer and development. These new actors often had no experience themselves of the learning acquired to work in their factory. However, they did have experience of other kinds of formal education in the academic tradition. Hence, one contribution to the VET field's coming into being was the dismantling of the guild system and the growth of industry. This brought together different actors that from different positions combat over the definition of good vocational education and training, how it was organised, measured and symbolised in merits. This struggle became a battle over which vocational education was 'the real vocational education and training'. The symbols would emphasise what was and what was not to be counted as real vocational education 
and the power to charge the symbols with value picked from two traditional institutions for learning: the guilds and academia.

Vocational skills were the epicentre of the guilds, and how to learn, evaluate and give merit to their participants united them as a field in terms of vocational education, even though the word education was not used at this time and in this context. The hierarchy in play within the guild system transferred into the VET field as a scale of values. There was a difference between master and journeyman and a difference between coopers and goldsmiths. In vocational education, there was a difference between types of education (courses, workshop schools, apprenticeship, etc.), between vocations to be trained in (hairdresser, photographer, electrician, carpenter, etc.) and between schools. Of course, this can be said about academia as well, but when structures of labour altered in the industrial era, the hierarchy of the old guild system was challenged by new occupations rather than by academic educations. New vocations, new techniques, new structures and actors became part of vocational skill production, a production previously maintained by guilds. At the same time education became available as idea and form of skill production through the implementation and expansion of general compulsory education. These developments are important context for VET as an education in the early $20^{\text {th }}$ century.

By the mid-1900s VET produced and reproduced itself as a field in a number of magazines, the most prominent example being the Tidskrift för praktiska ungdomsskolor. Concerns about VET were channelled through other journals as well, such as Industria and later on Yrkesläraren [The Vocational Teacher], for example. VET also managed to constitute national institutions of both a sector and a governmental kind. The previously mentioned Svenska yrkesskolföreningen, Arbetsmarknadens yrkesråd (AY) [Labour Market's Vocational Council] and Kungliga överstyrelsen för yrkesutbildning (KÖY) [The Royal Board of Vocational Education] were institutions constituted solely for the purpose of developing vocational education. Another actor was Sveriges hantverksorganisation (SHIO) [The Swedish Handicraft Organisation]. The Boards of the various schools were important actors as well. These were independent boards in the municipal organisation, consisting of a majority of persons from trade and industry. People holding positions in the VET field ranged from teachers, and traditional tradesmen or craftsmen, to industrial magnates and students.

In this study, students are regarded as part of the field. It could be argued that for students, their education is only a transitory period, as they are oriented towards other fields. But as this article focuses on practices creating VET educational capital and not the use of it, I conclude that the students were important contributors (direct and indirect) in this creation process (Bourdieu, 1986). It is also possible to include students as producers of capital in line with the argument that consumers (in this case the consumers of VET) contribute to the production of the product that is consumed (in this case the education capital of VET). This 
argument taken from $\mathrm{La}$ Distinction relates to the process of change within a field (Bourdieu, 1986, p. 241). Production is crucial and paradoxical; it both constitutes and transforms the field at the same time, and in that process, all actors in the field are producers.

It is important to note a distinction used in this article when referring to the VET system in Sweden from 1918 to 1971 as a field. I borrow the concept of field to visualise the stage setting for the actions, artefacts and narratives that are the main concern of this investigation: to narrate a process of creating VET educational capital. To investigate the field of VET at this time in history would shift focus to the structures-of-power relation. Although interesting and in need of investigation, this would be too extensive a scope for this article.

\section{Forms of capitals and habitus}

The operative concepts in this investigation are the symbolic capital and habitus (of different learning traditions) as they are used to create or empower VET educational capital in $20^{\text {th }}$ century Swedish VET as well as to symbolise the created capital. This is done in a dynamic production process of reusing symbolic values from different traditions and fields to create new symbols communicating new values (Bourdieu, 1992, 1995; Ullman, 1997). The concepts unveil narratives, artefacts, ceremonies and actions as contributors to this process.

The definition of symbolic capital can also be briefly defined as whatever is recognised as valuable by social groups. Symbolic capital signals other types of capital: education capital (type of education, level, institution of education), social capital (connections, associations, networks, social belonging), and cultural capital (preferences and knowledge of art, music, theatre, literature). Symbolic capital is the things, artefacts, titles, merits and ceremonies through which forms of capital can be visualised. Symbols are charged with a certain value made visible though materialisation or action (Bourdieu, 1995). This is also closely connected to the concept of habitus, since habitus describes the embodiment of social and cognitive skills, some of which can be recognised as symbolic capital, like wearing a school uniform, but it also relates to the way an individual or group talks or uses language in a particular way (Bourdieu, 2000). Hence, habitus reveals itself through language, behaviour and ways of thinking and practicing. This, like symbolic capital, is dependent on the social context of a field being understood correctly and being produced and reproduced. Habitus is an incorporated mastering of the practical, which is developed by participating in daily activities within the field. It is the bodily, verbal and cognitive transformation into a member of, for example, a vocational group. Situated learning as an apprentice is often related to the development of habitus and connected to specific vocational groups (Lave \& Wenger, 1991), but there are also interesting studies on the way the late $19^{\text {th }}$ and early $20^{\text {th }}$ century male middle class developed a class habitus 
through upper secondary elite educations (Florin \& Johansson, 1993). When studying Swedish VET in the mid-1900s we find many examples and indications of how the education contributed to a homogenic working-class habitus as well as a vocational-specific habitus.

\section{Recognising values creating vocational education capital}

The vocational education institutionalised in the early guilds had strategies, structures, ceremonials and merit systems that formed a field of craftsmanship where it was possible to accumulate cultural and symbolic capital, which was understood and which, to a certain extent, could be interpreted and recognised even outside the field. Bourdieu makes an important distinction between recognising, knowing something by sight, and recognition, as a deeper acknowledgement (Bourdieu, 1995, p. 97; Broady, 1998a). This means that the symbolic capital has at least two interrelated sides: one that makes a statement within the field and one that makes a statement in the surrounding society. One such symbol in the guild tradition was the title master and the message it conveyed to associate workers, society and presumed customers. The vocational teachers in the inschool workshop educations were even referred to as masters and journeymen's trials were adopted in some trades that lacked a clear heritage from a guild (TPU 1:1945, 7:1962). The master in the early guilds was responsible not only for the reproduction of skills in the trade but also for the socialisation of the apprentice into the vocational ethics and cultural codes. This vocational disciplinarian responsibility also appears in the VET of the $20^{\text {th }}$ century and is portrayed in different narratives, particularly in student memoirs (Larsson, 1991).

A number of articles in the Tidskrift för praktiska ungdomsskolor are biographical material that emphasise hard work, perseverance and physical interaction with material as the conditions for qualitative vocational knowing. A common text genre in the journal was biographicals, often narrating how the traditional artisan came into being. One example is the article Minnen från gesäll- och vandringsår [Memories from journeyman and wandering years] (TPU 9:1946) It tells the story of vocational teacher Werner Blom's many long journeys in Sweden and abroad, training with masters and becoming a skilled shoemaker.

Another narrative has a particular class perspective, the narrative of the diligent worker. The tradition that the narratives connect to - sometimes implicitly, sometimes explicitly - was one emanating from the guilds and their historical social responsibilities, quality standards and position in the local community (Edgren, 1987). By the early $20^{\text {th }}$ century, it had also taken on ideals communicated through social movements among the working class and lower-middle class (Ambjörnsson, 1988, 2011). The grand narrative or figure of thought that it is possible to recognise here is what Weber described as the Protestant ethic (Weber, 1978). The narrative of the diligent worker and the hard way to gain 
proficiency in a trade fused into the narrative of the vocational student as being part of a long and specific tradition of a trade and a class. It is important to recognise the diversity of vocations (from goldsmiths to plumbers) and vocational groups (in-school educations, apprenticeship at an industry school or in a smallscale craft business) within VET. The examples below can be seen an effort to both create and symbolise VET educational capital. It may also be interpreted as part of a defining process - or closure - to distinguish a particular 'us' from 'them'. Defining processes are part of the struggle and the moving of positions within the field that structure and define it.

The master in the school workshop was expected to be the embodiment of the work ethic and to exemplify the ways of thinking and practicing that upheld the differences from both the white-collar vocations and the unspecified workers without education or training in that specific craft. This discourse is particularly evident in articles problematising the different norms and standards the students encountered when they were doing their workplace training, as in this example of differing work ethics between school and workplace:

The work ethics of the adults [at the workplace] must in many cases be improved. How can the poor vocational teacher keep the students in the building when the lights are turned off a quarter of an hour earlier? (TPU 4:1967, p. 245 [emphasis in original])

The idea that VET had a responsibility to discipline future workers is its reproduction of schooling as well as in the production of vocational knowing for contemporary needs. Another example is the grounds for employment as a VET teacher. Character was an important qualification. According to documents in school archives 'zeal', 'honourable conduct', 'dedicated', 'careful', and the ability to maintain 'law and order'] were valued assets as vocational teacher (LYS B4:1 Tjänstgöringsbetyg och förordnanden).

The students were socialised into the tradition of a good work ethic. Punctuality, cleanliness and good order were taught and rewarded, and the breaking of norms was punished by the system of diligence money (a form of apprenticeship pay, but for in-school workshop students). As one man recollects, the master could fine a student (take away the diligence money) for leaving a blunt tool unsharpened for the next user or even for breaking wind, as behaviour violating the norm of professional conduct (Larsson, 1991). At the same time, a sign of belonging and of the ability to read or interpret the constitutions of a specific vocation was when the vocational students could enjoy a laugh at the expense of whitecollar representatives. The following example is from an article arguing for the importance of VET and the qualitative differences of vocational knowing in different vocational groups working together. A master in a workshop school reported: 
Now it is so that a craftsman can see from a blueprint how much practical experience the constructor has. [...] The boys know nothing funnier than finding a mistake in the drawings the clients have handed in for manufacture at the school (TPU 3:1945, p. 101)

Humour such as this is a kind of language specific to a group, and as such, the habitus of an individual in the group would be to understand the fun. Habitus generates strategies in the social milieu one encounters. The master's pride in his students not only emanated from the knowledge they showed but also underlined the community they shared, which became visible in the encounter with another social milieu. It is possible to interpret the laughter at the drawings from the architect's office as an expression of habitus produced or constructed within the vocational education and training. Underlining this expression is not only the social difference between different educational backgrounds but also, and perhaps most important, the use of knowledge unique to the educational tradition of vocational skills mediated in the VET system of schools.

Another example that reveals the norms that the schooling sought to develop in the vocational student is the struggle for the exclusive right to the name vocational student. There were indignant articles in Tidskrift för praktiska ungdomsskolor about juvenile delinquents in correctional institutions being called vocational education students (TPU 5:1955, 9:1959, 7:1962, 9:1962). The groups of interests in vocational education fought hard to make the Ministry of Social Affairs change the wording in the official language concerning the juvenile delinquents participating in correctional programmes where they trained for work. The vocational students were pictured as embodying the moral virtues of hard work and honesty, the complete opposite of the other group of unfortunate young people in the institutions. Thus, it was the habitus developed or embodied in vocational education that would single out the vocational student, and in this respect, he or she also became a trademark of VET. The charging of the name 'vocational student' with moral virtues contributed to the construction of the symbolic capital VET could generate. To say you were a vocational student would carry a positive meaning, not only for the future employer or fellow craftsman but for the surrounding community as well. The educational capital of VET was in this case symbolised by the definition of a VET student and embodied in the students' habitus which in turn made the individual VET student a symbolic capital for VET. The norms of the context developing the vocational student habitus were illustrated in the lyrics of songs written by students for end-of-semester ceremonies, as when the Vocational Schools of Stockholm celebrated the end of another academic year at Skansen in 1948. The song honoured the students' knowledge and virtues, vocation by vocation, as in these verses:

When a house is to be built we blast the rock,

Build the walls, do the carpentry and paint the wood. 
Åsa Broberg

And with fine interior decoration

Our upholsterers complete the job

In our school years we are short of cash

While our comrades get well paid.

But in life we soon found out

That a real craftsman

Earns more than he who knows nothing.

We have learnt at LYS in these hard years

How to gain some lasting knowledge.

Those who chose an easier way

We shall soon pass by.

They stand still while we move on fast.

[...]

We take great interest in all around us.

We want to learn more about everything.

An open mind and open eyes

For our society is what our LYS gave us.

(LYS Styrelseprotokoll, A1A 1920-196)

It was clearly also a celebration of the school and the education it provided which brought forth these excellent workers.

In 1952, vocational students at an in-school workshop of mechanical education took the initiative to create a school signet ring.

A ring is rarely (if ever) just a ring. A ring is a bodily-worn symbol of something: a marriage, a title, economic wealth, family tradition, education and so on. This is important since it signals some form of social or cultural capital. The interpretation or recognition of its value is made within a social field.

The Board treated the request from the students in a subsequent minute. First it ruled in favour of letting the students make a ring. It also decided that the Board would contribute to the initiative by sending a request to the city council to use the official seal of the community as an engraving on the ring. This was approved, and the Board decided to purchase the necessary machinery to manufacture the ring (FSU, Styrelseprotokoll 20/5 1952 § 68, A4A:1). The students and the representatives of the school and the municipal authorities came together in the idea of a need to embody the knowledge and experience gained from this particular education, and as the official seal signals, from a particular school. The ring was at the same time specific to trade, education and the school. Most likely the narrative to support the symbol was connected to the tradition of guilds, where historically there are examples of master rings (Figure 1). In this example, we know little about what trade the students were in (other than some kind of mechanical vocation), but there is another example of school ring that was created on the initiative of students in industrial vocations. This was an industrial school with a 
private organiser (one of many educational forms in the 1918 VET system) in the small industrial town of Laxå (Henriksén, 2008). Being a group of interests within the field of VET, this industry is complex. New vocations were created in the industry that could not trace their origin to a craft. The idea of a ring might therefore also have been inspired by the academic tradition, but once again, the students took the initiative and the engraving on the ring in this case clearly symbolised skills associated with workshop vocations as it figured a hammer and a spanner (Figure 2). In both cases, the in-school workshop in Huddinge (municipal organiser) and the industrial school in Laxå (private organiser) students and administration worked together to create VET educational capital by reusing the symbolic value of a master ring, which in turn symbolised a value system of quality vocational knowing. But rings are also used in the academic tradition to symbolise the highest degree of education. The two schools were examples of the new educational forms in vocational learning, for example in-school workshops, organised not by a craftsman in a small business as an apprenticeship. The academic tradition may have been represented by the organisers; in any case, the men on the school boards could easily recognise the symbol of a ring as related to either learning tradition. Thus, these rings were recognisable by both craft and industry, and perhaps even academia. They signalled the importance of VET and the particular schools by drawing on the historical credit of two learning traditions.

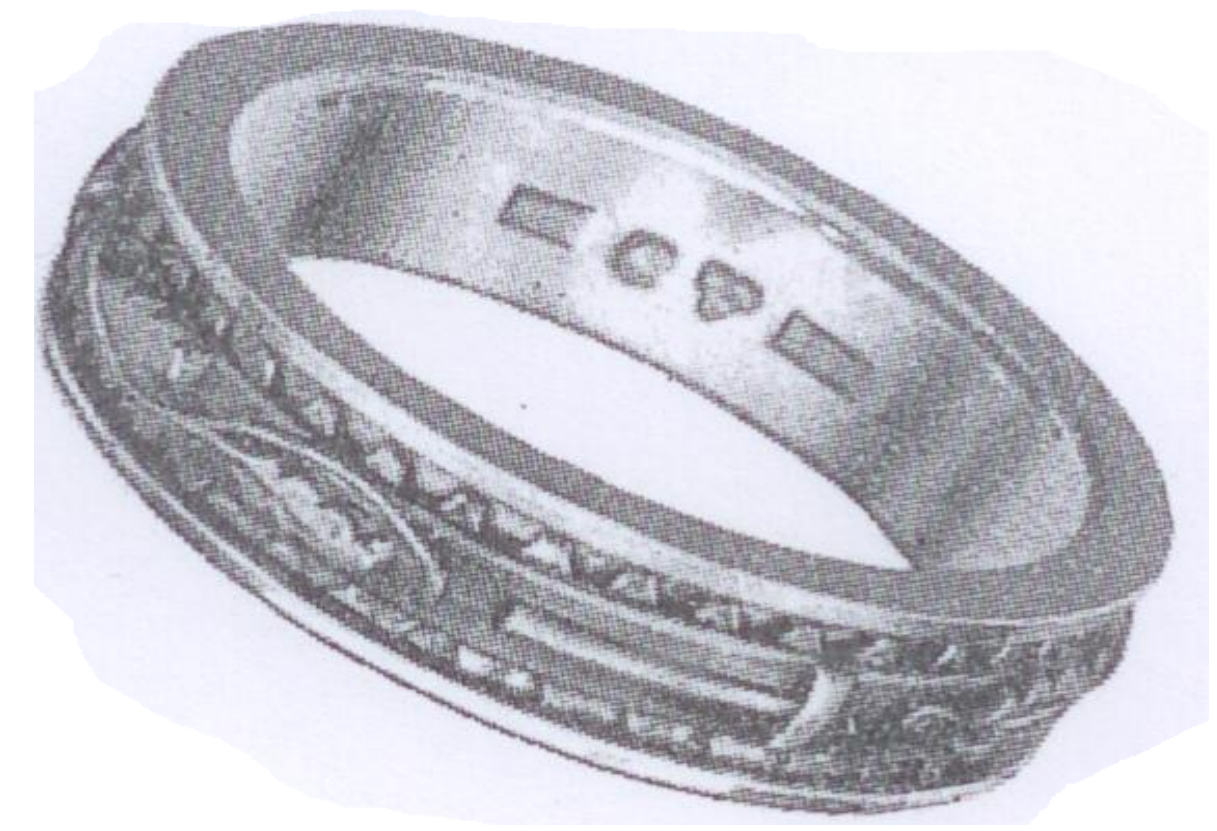

Figure 1. A master ring (TPU 2:1947). 


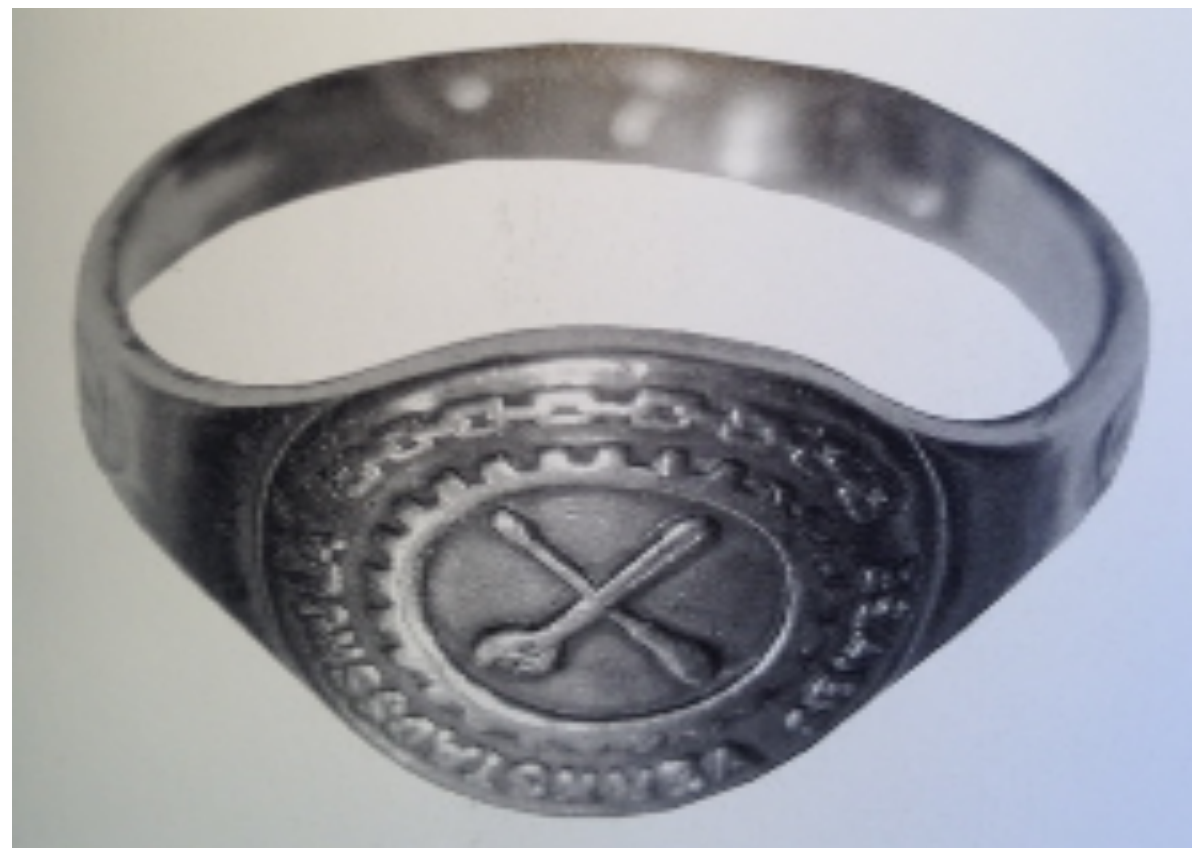

Figure 2. School ring for industrial educations in the workshop school of ESAB in Laxå, Sweden (Henriksén, 2008).

Another way of constructing VET educational capital by this optimising use of two-tradition symbols, as in the cases of the rings, was to mark the end-of-semester ceremonials. Stockholm Vocational schools held their ceremonies in the City Hall and in Blå Hallen (The Blue Hall). This is a place with high ceremonial ambiance. It is the room where the Nobel Prize ceremony is held. Photos from the archive show men and women in formal dress, white for the women sitting on the right side and black for the men seated on the left side, as they all face the speaker at the rostrum (Figure 3) (LYS F5 Fotografier). The palatial or even church-like architecture of the City Hall underlines the importance of the ceremony taking place there. It is not going too far to compare this ceremony with the Stockholm University conferment of a doctor's degree. 


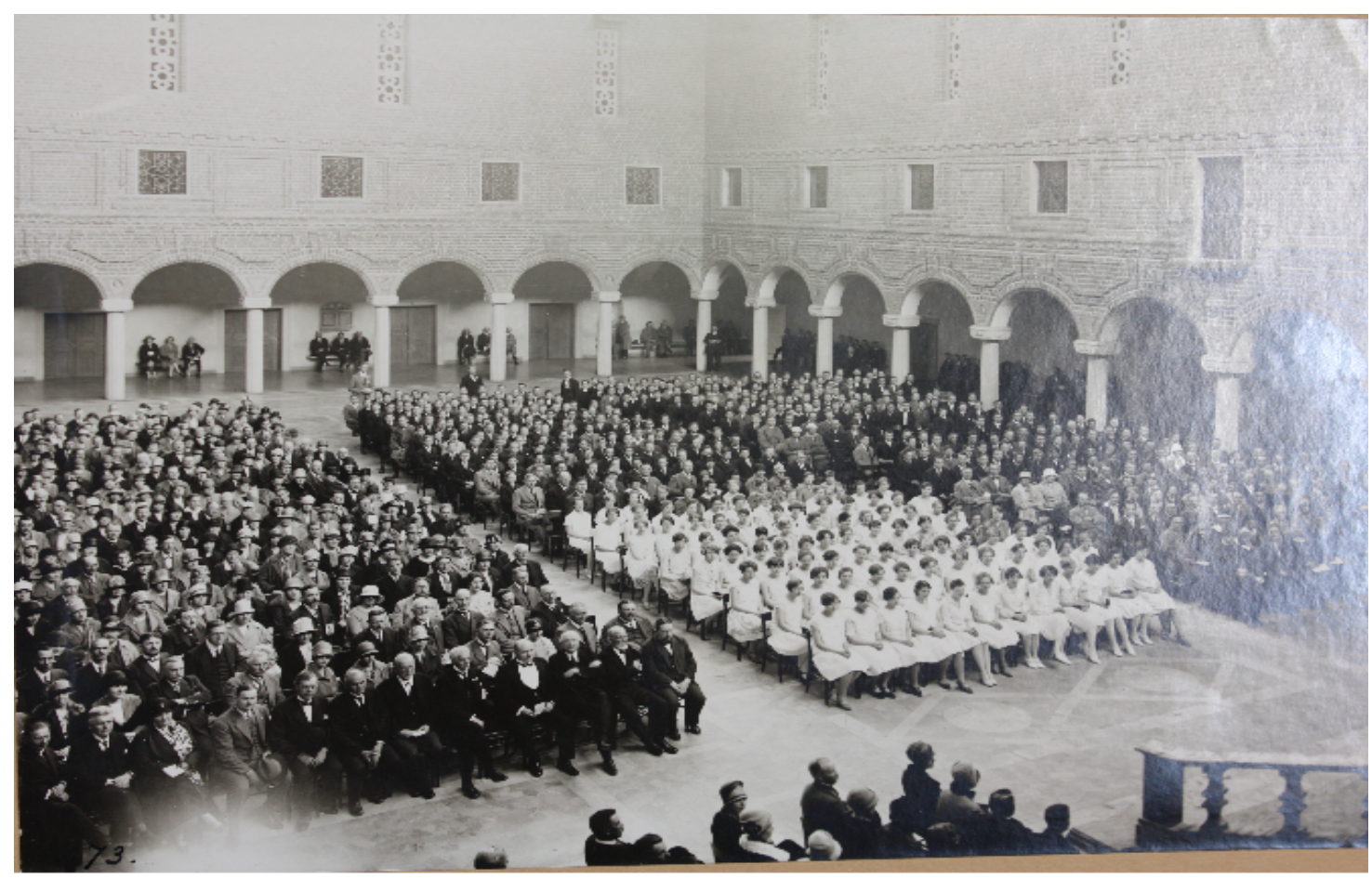

Figure 1. End of semester ceremonial of Stockholm Vocational schools (probably 1920s). An item in the programme was appointing journeymen. Source: Municipal archives of Stockholm.

It is possible to claim that this ceremony emulates the traits and traditions of academia and claims a comparative acknowledgement of their merits. However, the actual procedure in this setting had its roots in the guild meriting system. Part of the ceremony in the City Hall in the early VET was also the official appointment of new journeymen by giving them their diplomas and medals. The graduations in Blå Hallen were most likely intended to imitate the traditional crafts for the more modern vocations, as well as for female educations, which lacked the traditions of a journeyman's test and a journeyman's certificate. A craft education still ranked higher within the field; the ring and award ceremony alluding to the guild tradition would reinforce vocational learning as education as such, not as an education in comparison with an academic education. The ceremony symbolised VET education capital communicating its value, to be recognised both inside and outside the field. Within the field of VET the tradition of craft was a currency that could empower modern vocations and new educational forms. New vocation students in this context were, for example, car mechanics who would have trouble tracing any roots back to a guild, but also female vocations, as women were traditionally not associated with the guilds. New groups within the field of 
Åsa Broberg

VET were challenging the doxa of how to develop quality vocational knowing by using the currency once monopolised by the crafts though its historical heritage of the guilds.

The ceremony setting's double allusion to the history of the guilds and the history of academia signalled a symbolic value equal to the academic tradition, but within the vocational education field. This is a crucial point. Based on the assumption that a field also functions as a market, I argue that the symbolic value established by these types of ceremonies and likewise the ring in Huddinge and in Laxå could be exchanged in the middle of the $20^{\text {th }}$ century because the academic tradition was a completely different field/market with a different currency.

The students passed through the social field of vocational education and training, but it is important not to underestimate their part in formulating and participating in the making of VET educational capital, and their efforts to accumulate VET educational capital. The initiatives of making the rings and the song written for the ceremony at Skansen indicate that they were involved in producing and reproducing the symbolic value of vocational education. The importance of the vocational student as a symbol and the stories that reveal the standards of a qualified worker were not generated by the students but rather lived by them. They experienced masters, penalties and rewards, ceremonies, humour, systems of merits and standards and symbols materialising or institutionalising these truths about vocational education, blue-collar vocations and vocational knowledge.

\section{Concluding discussion}

The VET field in early $20^{\text {th }}$ century Sweden, which was built round the question of education for the transfer of skills and the charging of its symbols, was generated in the struggle over what was to be counted as 'real' or 'actual' vocational education. This was a field created by actors, organisations, associations, school boards and institutions, and by systems of credits and ongoing discussions through papers and conventions. VET in the early Swedish model created educational capital by merging the traditions of the guilds and academia and using their symbols in new ways - but recognisable in the VET field. Findings in the empirical material of rituals and artefacts such as ceremonies in the city hall, school rings and songs are examples of this. This symbolic capital was used to communicate the value of VET in relation to other educations (to attract students) and to the labour market (to build up both industrial and craft employers' confidence). The lyrics in the song about knowledgeable craftsmanship and the struggle to keep the definition of 'vocational student' tide to the discourse of the diligent worker is examples ways to produce symbolic capital in and for VET as an education. 
The VET field as structured by the conditions of the educational system of the time (1918-1971) gradually disintegrated in the stepwise integration of the independent school boards into the primary and secondary municipal school organisation (Broberg, 2014). On the national level, the government authority dedicated solely to vocational education closed down and its resources were integrated into the state-regulated national education system. In doing so, the trade and industry that previously had a significant influence though the cooperative organisation AY saw their mandate diminished (Olofsson, 2001, 2005). The fact that the organisation SYF and its journal Tidskrift för praktiska ungdomsskolor (by 1968 it had been renamed Tidskrift för yrkesutbildning) closed down in the aftermath of the 1971 reform also illustrates a transformation of what distinguished the early Swedish VET field. What really rearranged and perhaps weakened the field was the loss of authority over the definition of what 'real vocational education' was. The process of historical reproduction of education affected VET by its integration into the 'gymnasium', an upper secondary level previously providing academic education only. This merger meant that there were no different forms of vocational education to compare with. VET from 1971 was a two-year, upper secondary, inschool programme and preparatory (no vocational exams like journeymen were issued by this education) regardless of the vocation it was preparing for. One possible conclusion is that this new system affected the possibility to build hierarchies within VET, between vocational education programmes. Thus the struggle to define what real vocational education was disappeared when the uppersecondary education organisation erased the heterogeneity of VET educational forms. This historical development altered the rules of engagement, which affected not only the positions and structures but also the systems of value determining the currency of vocational education capital. In the early model of VET, different vocational education forms competed for the high symbolic assets. In the new field, there were only academic educations to compete with. The symbols charged with value from the guild tradition became, in the new field, a foreign currency with no exchange value. With the field of vocational education disbanded or divided into sub-fields with no clear connections, there were no social fields where the symbols - fused by both the guild and the academic tradition, forming an exclusively 'VET currency' - could be interpreted and recognised. During a period of a little more than 50 years, the struggle to define good vocational education and training was developing while new occupations and gender structures were emerging. As a field, the actors and dynamics shifted and altered, the symbols were charged and recharged, and it was perhaps because the currency remained exclusive to the field that VET could to some extent be perceived in its own right.

The symbols from both crafts and academia were passed on through the early VET system through its institutions and actors and the values negotiated within the field. The transfer of a symbol, a title such as journeyman or master from 
Åsa Broberg

historical times to a modern practice, does not mean that it is given the same content. It is rather a 'passing on of an earlier scale of value and status of the title', and herein lies both continuity and change (Ullman, 1997, p. 22). Today the title of master or journeyman is not associated with vocational education at the upper secondary level. It does not symbolise the same skills as in the guilds or the early $20^{\text {th }}$ century Swedish VET, but it is empowered by the historical scale of value. That means it continues to be a valuable symbolic capital, but not of education gained from the national vocational education system. The passing on of this particular scale of values through titles, narratives, rituals and artefacts is now, with very few exceptions, administered by educational organisers outside the statefunded national education system. The early social field of VET consolidated vocational education capital through tensions between traditions and the legacy of different scales of values. These tensions were lost in the process of turning vocational education into upper secondary, school-based education regulated in the same way as academic education. What this loss of tension means for Swedish vocational education and training in terms of accumulating educational and symbolic capital and gaining recognition as valuable education capital remains to be investigated and discussed. As suggested in the introduction the process of creating vocational education capital can be identified in the development of VET in all Nordic countries but the conditions are different depending on the field. The possibilities to uphold, transform and manage values turned into capital are closely related to the esteem of VET. The esteem of VET today is recognised in research to be a shared problem although different in character (Larsen \& Persson Thunqvist, 2018). The Nordic countries have developed differently in terms of regulating the relations between education and stakeholders (Michelsen \& Stenström, 2018). This also means differences in structures of VET as a field and the process of constructing VET capital. A way of understanding this particular challenge is perhaps to understand the rules of engagement for VET as a social field and its historical development.

\section{Endnotes}

1 For statistical data on the number of students involved in VET, see Statistiska centralbyrån (1984). The period is also characterised by its many governmental inquiries involving VET or focusing on VET especially. See, for example, the public reports, SOU 1954:11 and SOU 1966:3.

2 Research using this theoretical approach to understanding VET is usually related to learning and vocational skills, for example in Colley et al. (2003) or in Rehn and Eliasson (2015). The Bourdieuan concepts used to investigate VET models are less common; however, the thesis of Nylund (2013) should be mentioned as well as the article by Nylund (2012). 
Note on contributor

Åsa Broberg is senior lecturer in education with a focus on educational history and has a background as a historian and a teacher. She received her PhD in 2014 on her thesis Education on the border between school and work: Educational change in Swedish vocational education 1918-1971. Research interests revolve around the challenges of vocational training. 
Åsa Broberg

\section{Source material (Unpublished)}

Archive

Huddinge kommunarkiv [Municipal archive of Huddinge]

FSU, Styrelseprotokoll [Minutes] 20/5 1952 § 68, A4A:1.

Stockholms stadsarkiv [City archive of Stockholm]

LYS Styrelseprotokoll [Minutes] A1A 1920-1963.

LYS B4: 1 Tjänstgöringsbetyg och förordnanden [CV records and appointments].

LYS F5 Fotografier [Photographs].

\section{Source material (Published)}

Articles in Tidskrift för praktiska ungdomsskolor (TPU) [Journal of Youth Vocational Schools]

Gesällprovet i verkstadsskolan [The apprenticeship test in vocational schools] 1:1945.

Ett genmäle: Yrkesläraren och teoriundervisningen [A reply: The vocational teacher and theoretical education] 3:1945.

Minnen från gesäll- och vandringsår [Memories from apprentice and wandering years] 9:1946.

Yrkesskoleelever på vansinnesfärd [Vocational school students on a mad journey] 5:1955.

Yrkesskolvärlden säger nej [The vocational school says no] 2:1956.

O.W. Andersson - åskans broder - en av de stora i yrkesskolvärlden [O.W. Andersson - the brother of thunder - one of the great men in the vocational school world] 1:1957.

Synpunkter [Opinions] 9:1959.

Hel avslutningsklass klarade gesällprov [Entire class qualified in journeyman's test] 7:1962.

Yrkesskoledirektör säger ifrån om kränkande rubriker [Vocational school principal refutes offensive headlines] 7:1962.

En fin julklapp [A lovely Christmas present] 9:1962.

Byggnadsutbildning i Hälsingland [Construction education in Hälsingland] 4:1967. 


\section{Memory books}

Henriksén, J-E. (2008). ESABs Verkstadsskola i Laxå 1949-1971: En historisk återblick på skolan, eleverna och företaget [ESAB's workshop school in Laxå 1949-1971: A history of the school, the students and the company]. Mjölby: Atremi.

Larsson, S-A. (Ed.) (1991). Från yrkesskola till S:t Eriks Gymnasium [From vocational School to S:t Erik's Gymnasium]. Stockholm: S:t Eriks Gymnasium.

\section{References}

Ambjörnsson, R. (1988). Den skötsamme arbetaren: Idéer och ideal $i$ ett norrländskt sågverkssamhälle 1880-1930 [The diligent worker: Ideas and ideals in a Norrland sawmill community]. Stockholm: Carlsson.

Ambjörnsson, R. (2011). Mitt förnamn är Ronny: Berättelsen om en klassresa [My first name is Ronny: The story of a class journey]. Stockholm: Atlas.

Berner, B. (1986). Kunskapens vägar: Teknik och lärande i skola och arbetsliv [The ways of knowledge: Technology and learning in school and working life]. Lund: Arkiv.

Bourdieu, P. (1986). La Distinction [Distinction]. In Kultursociologiska texter. I urval av Donald Brody och Mikael Palme [Cultural-sociological texts. Selected by Donald Brody and Mikael Palme]. Stockholm: Salamander.

Bourdieu, P. (1991). Kultur och kritik [Culture and critique]. Göteborg: Daidalos.

Bourdieu, P. (1992). Några egenskaper hos fälten [Properties of the fields]. In D. Broady (Ed.), Texter om de intellektuella: en antologi [Texts about the intellectuals: An anthology]. Stockholm: Symposium.

Bourdieu, P. (1995). Praktiskt förnuft: Bidrag till en handlingsteori [Practical reason: On the theory of action]. Göteborg: Daidalos.

Bourdieu, P. (2000). Konstens regler: Det litterära fältets uppkomst och struktur [Rules of art: Genesis and structure of the literary field]. Stockholm: Brutus Östlings Bokförlag Symposium.

Bourdieu, P., \& Chartier, R. (2015). The sociologist and the historian. Cambridge: Polity Press.

Broady, D. (1998a). Kapitalbegreppet som utbildningssociologiskt verktyg [The concept of capital as an educational-sociological tool]. Uppsala: Skeptron Occasional papers $\mathrm{Nr} 15$.

Broady, D. (1998b). Kulturens fält: En antologi [The field of culture: An anthology]. Göteborg: Daidalos.

Broberg, A. (2014). Utbildning på gränsen mellan skola och arbete: Pedagogisk förändring $i$ svensk yrkesutbildning 1918-1971 [Education on the border between school and work: Educational change in Swedish vocational education and training 1918-1971]. Stockholm: Stockholms universitet. 
Åsa Broberg

Colley, H., James, D., Diment, K., \& Tedder, M. (2003). Learning as becoming in vocational education and training: Class gender end the role of vocational habitus. Journal of Vocational Education \& Training, 55(4), 471-498.

Edgren, L. (1987). Lärling - gesäll - mästare: Hantverk och hantverkare i Malmö 17501847 [Apprentice - journeyman - master: Crafts and craftsmen in Malmö 1750-1847]. Lund: Dialogos.

Eliasson E., \& Rehn, H. (2015). Caring disposition and subordination: Swedish health- and social-care teachers' conceptions of important vocational knowledge. Journal of Vocational education E Training, 67(4), 558-577.

Florin, C., \& Johansson, U. (1993). "Där de härliga lagrarna gro...": Kultur, klass och kön $i$ det svenska läroverket 1850-1914 ['Where the glorious laurel wreaths may grow...': Culture, class and gender in the Swedish grammar school]. Stockholm: Tiden.

Hellstrand, S. (2020). Lärlingsfrågan: Institutionell förändring, ekonomiska föreställningar och historiska begrepp i den svenska debatten om lärlingsutbildningen, 18901917 [The apprentice question: Institutional change, economic perception and historical concepts in the Swedish debate of apprentice training, 1890-1917]. Stockholm: Stockholms universitet.

Larsen, L., \& Persson Thunqvist, D. (2018). Balancing the esteem of vocational education and social inclusion in four Nordic countries. In C.H. Jørgensen, O.J. Olsen, \& D. Persson Thunqvist (Eds.), Vocational education in the Nordic countries: Learning from diversity (pp. 76-94). Milton Park, Abingdon, Oxon: Routledge.

Lave, J., \& Wenger, E. (1991). Situated learning: Legitimate peripheral participation. Cambridge: Cambridge University Press.

Lindell, I. (1992). Disciplinering och yrkesutbildning: Reformarbetet bakom 1918 års praktiska ungdomsskolereform [Discipline and vocational education: The path towards the educational reform of 1918]. Uppsala: Föreningen för svensk undervisningshistoria.

Lindensjö, B., \& Lundgren, U.P. (2014). Utbildningsreformer och politisk styrning [Educational reforms and political governance]. Stockholm: Liber.

Margolis, E., \& Fram, S. (2007). Caught napping: Images of surveillance, discipline and punishment on the body of the schoolchild. History of Education, 36(2), 191-211.

Michelsen, S. (2018). The historical evolution of vocational education in the Nordic countries. In S. Michelsen, \& M. Stenström (Eds.), Vocational education in the Nordic countries: The historical evolution (pp. 1-23). London: Routledge.

Michelsen, S. \& Stenström, M. (Eds.). Vocational education in the Nordic countries: The historical evolution. London: Routledge.

Nylund, M. (2012). The relevance of class in education policy and research: The case of Sweden's vocational education. Education Inquiry, 3(4), 591-613. 
Nylund, M. (2013). Yrkesutbildning, klass och kunskap: En studie om sociala och politiska implikationer av innehällets organisering $i$ yrkesorienterad utbildning med fokus på 2011 års gymnasiereform [Vocational education, class and knowledge: A study of social and political implications of content organization focusing on upper secondary school reform of 2011]. Örebro: Örebro universitet.

Olofsson, J. (2001). Partsorganisationerna och industrins yrkesutbildning 19181971: En svensk modell för central trepartssamverkan [The trade and industry organisations and vocational education for industry 1918-1971: A Swedish model for central triangular cooperation]. Scandia, 1, 2001, 61-106.

Olofsson, J. (2005). Svensk yrkesutbildning: Vägval i internationell belysning [Swedish vocational education: Choices from an international perspective]. Stockholm: SNS.

Ullman, A. (1997). Rektorn: En studie av en titel och dess bärare [The Principal: A study of a title and its carrier]. Stockholm: Stockholms universitet.

Selander, S., \& Ödman, P-J. (Eds.) (2005). Text och existens: Hermeneutik möter samhällsvetenskap [Text and existence: Hermeneutics meets social science]. Göteborg: Daidalos.

SOU 1954:11. Yrkesutbildningen: Betänkande av 1952 års yrkesskolsakkunniga [Vocational education: Report from the commission on vocational education and training]. Stockholm: Nordiska Bokhandeln.

SOU 1966:3. Yrkesutbildningen: Yrkesutbildningsberedningen 1 [Vocational education: Edvisory committee 1]. Stockholm: H. Olsson.

Statistiska Centralbyrån. (1984). Elever i skolor för yrkesutbildning 1844-1970 [Pupils in schools of vocational education in Sweden 1844-1970]. Stockholm: Statistiska centralbyrån.

Watt Boolsen, M. (2007) Kvalitativa analyser: Forskningsprocess, människa, samhälle [Qualitative analysis: Research process, man, society]. Malmö: Gleerup.

Weber, M. (1978). Den protestantiska etiken och kapitalismens anda [The protestant ethic and the spirit of capitalism]. Lund: Argos. 